\title{
Overview of the Anthropogenic Causes of Soil Erosion in Auchi, Edo State, Nigeria
}

\author{
Ajayi A. $\mathrm{S}^{1} \quad$ Ibrahim Rasheed $^{1} \quad$ Seghosime Sule $^{2}$ \\ 1.Department of Agricultural and Bio-Environmental Engineering Technology, Auchi Polytechnic Auchi, Edo \\ State Nigeria \\ 2.Department of Civil Engineering Technology, Auchi Polytechnic Auchi Edo State Nigeria
}

\begin{abstract}
The incidence of gully erosion in Auchi, Edo State has assumed alarming proportions thereby gaining national recognition as an ecological disaster zone. The aim of this paper is therefore to examine some of the human causes of this menace and its impact on the population of the area and coping strategies adopted by individuals, community and the government. From field survey and observation, some of the anthropogenic causes found were: Dumping of refuse in water channels and drainages, Excavation of soil for building and other purposes, Poor siting of fences, Deforestation, Bush burning, Building and road Construction factors and Erection of residential structures without drainage and some of the possible control measures are: Environmental education, Environmental surveillance, the use of Vegetation and proper Solid waste management.
\end{abstract}

Keywords: Soil erosion, Anthropogenic influences, environmental surveillance \& education, Auchi

DOI: $10.7176 / \mathrm{JEES} / 9-8-02$

Publication date: August $31^{\text {st }} 2019$

\subsection{Introduction}

Soil degradation has important impact on the functioning of the socio-economic and environmental constituent of any ecosystem, it is associated with important tradeoffs for sustainability, food security, biodiversity and the vulnerability of people and ecosystem to an overall change impact (Lesschen et al., 2005). Put differently, it refers to the reduction in the value and quality of a given soil through alteration in such a way as to render it unsuitable for its best use. As a total expression of an inordinate land - use cover change, a phenomenon that apparently undermines the true potential of a landscape for its immediate or future use. The concept of land or soil degradation are often used interchangeably to represent certain fundamental changes which often manifest as the interplay between socioeconomic, institutional and environment factors (Egbai et al., 2011).

Erosion can be classified according to its cause; whether geologic or accelerated, Geologic erosion is a normal process of weathering that generally occurs at low rates in all soils as part of the natural soil-forming processes. In contrast, soil erosion becomes a major concern when the rate of erosion exceeds a certain threshold level and becomes rapid, known as accelerated erosion. This type of erosion is triggered by anthropogenic(human) causes such as deforestation, slash-and burn agriculture, intensive plowing, intensive and uncontrolled grazing, and biomass burning (Humberto and Rattan, 2008). It is generally clear that the more the population of an area increases, the more the need and use of land in the area increases, especially if some of the food needs of the population are not imported (Uche, 2012). Soil erosion is one of the environmental problems that affect the whole world but generally, it is more prominent in the tropical countries. Erosion rates are major factors of interest in order to combat the problems posed by gullies. It is estimated that over $90 \%$ of Nigeria's total land area is under, rill and gully erosion (FGN, 1997).

Erosion is endemic in Nigeria. There are prominent erosion sites in Nigeria especially in the east and southsouth. Nnebedum (2013) attributed the genesis and growth of gullies to human activities and geomorphologic processes, most of the activities could have been averted by human but either by commission or omission they are not taken care of. According to Ojo (1973), gully erosion is due to geological, hydro geological and geotechnical problems with ecological consequences when left unchecked. To be successful in the fight against erosion, the factors, causes and consequences must be well understood so as to manage it effectively. The aim of this paper is to highlight some of the anomalous and disastrous human activities that are the causes of soil erosion by water in Auchi metropolis and to proffer possible solution to the menace.

\subsection{Erosion Menace in Auchi Town}

Auchi is one of the fastest growing urban areas in Edo State. It is located between latitude $7^{0} 10^{\prime}$ and $7^{0} 20^{\prime}$ north of the equator and longitude $6^{0} 16^{\prime}$ and $6^{0} 36^{\prime}$ east of the Greenwich Meridian. This area is made up of several quarters; they are Abotse, Ibie, Afadokhai, Usogun, Egeroso, Akpekpe, Iyekhei, Igbe, Iyetse and Afobomhe. This area experiences the humid tropical climate, which is characterized by wet and dry seasons. The topography is relatively undulating and it slopes from the north of the area to the south. The soil type is the loose sandy soil, which makes it susceptible to erosion. Auchi gully erosion problem has become a source of worry to many people including traditional leaders in the area and Nigerians in general because of the economic and strategic importance 
of the town. So far, the menace has defied all palliative measures by the community, as the situation is continually getting worse. In the 2006 census, the study area had a population of 142,819 people. It has a total land area of $358 \mathrm{Km}^{2}$ (Ojeifo and Akhimien, 2013).

\subsection{Anthropogenic causes of Soil erosion in Auchi}

\subsection{Dumping of refuse in water channels and drainages}

Heaps of municipal solid wastes and unsightly waste dumps are common sights in Auchi town, the residents are fond of converting free water ways to refuse disposal points especially during rainy season with the aim of the refuse being dispersed by water to other places and this has caused major blockage for the free movement of water, the water now finds another route for its self, it moves and erodes the land and houses because the free water channel has been blocked. Same with other Nigerian cities, the estimated per capita waste generation for Nigeria is about $0.5 \mathrm{~kg}$ per person per day (Mbajiorgu, 2008), this figure may seem small at the individual level, but at the city level, the figures can become staggering. With urban population on the increase, Lagos city alone generates about 500,000 metric tons of solid waste each day. It is common to see streets overtaken by garbage and drainages filled with solid wastes, thereby blocking accessibility to runoff, overland flow and other surface waters.

\subsection{Excavation of Sand for building and other purposes}

As a fast growing cosmopolitan city, Auchi in the past ten (10) years has experienced unprecedented infrastructural expansion, structures and residential buildings are being erected on a daily basis and that has created a dearth of sand and other naturally occurring building materials, so people now resort to excavating sand from the streets and close to their building sites for molding blocks/bricks and this on the other hand has created room for ponding of water and excessive steep slope for runoff which invariably leads to serious land degradation.

\subsection{Poor siting of fences}

Ojeifo and Akhimien (2013) studied the impact of fencing pattern on Auchi environment and found that Auchi is erosion and flood prone area because the pattern of building makes erosion intense and invasive in the area. Fences on natural water courses have created other channels which have led to the emergence of heavy gullies. The damage to land and social infrastructure by erosion in the area is difficult to quantify. The study reveals that over 25 houses have been lost to erosion in the last 5 years while roads, electric poles, and other facilities have been eroded or destroyed by erosion.

\subsection{Deforestation}

Deforestation is a well-known factor because people especially in the developing countries cut the tropical forest just for exportation to earn foreign exchange and provision of wood for different purposes, like construction of houses, firewood's, bridges, roads, and other construction purposes. In Auchi town, deforestation is a common activity because the residents fetch fire wood for cooking, logs for building and other purposes, and this has been the major reason some of the lands are exposed to direct influence of the scouring action of rain drops that invariably grow to become gullies.

\subsection{Bush Burning}

Bush burning especially in dry season is a common practice in Auchi, this is usually practiced for many beneficial reasons like hunting, and conserving the cost of land clearing but it has adverse effects; this factor removes the soil cover and burns the micro-organisms that binds the soil aggregates. The removal of vegetation exposes the soil to erosion.

\subsection{Building and Road Construction factors}

The poor construction of roads in Auchi without the normal fortification and stabilization of the roads' slopes accelerates erosion on most roads. This is because of general poor planning and poor financial of construction works done in these countries. In Nigeria, Egboka et. al., (1993) noted that "The construction agents build or commission surfaced/tarred or un-tarred roads without culverts or stabilized sidewalls and drainage channels. These roads soon become gully channels".

\subsection{Construction of Residential Structures without Drainage}

The indiscriminate erection of residential buildings and other structures is one of the major causes of erosion in this area because of rapid infrastructural development currently ongoing. From field survey around Auchi, it was observed that majority of the houses don't have drainage systems/gutters around that dispose rain and waste water to safe points, and some of these houses can't be inhabited again as water has check in because of anomalous practices. 


\subsection{Prevention and Control}

\subsection{Environmental Education}

This refers to organized efforts to teach about how natural environments function and particularly, how human beings can manage their behavior and ecosystems in order to live sustainably (Wikipedia, 2014). It also entails the process of increasing people's knowledge and awareness about the environment and associated challenges. Religious gatherings, mass media and other medium can be used to bring about this form of education, sensitizing the people on safe practices that curbs erosion and land degradation.

\subsection{Environmental Surveillance}

This is a system of monitoring the environment in order to protect lands from degradation. It entails establishing laws and orders to regulate and curb these anthropogenic activities, beyond the general environmental sanitation program, this environmental surveillance program will help keep an eye on specific locations where this environmentally unfriendly acts are practiced in order to avoid the anomalous practices and also to arrest and prosecute defaulters, this will go a long way to restraining the loss of whole properties and lives.

\subsection{The use of Vegetation}

Vegetation makes use of grasses, trees and other plants to protect slopes from Erosion, and improve the geotechnical properties of soil. Soil Bioengineering is now an established practice in many parts of the world and is considered a practical alternative to more traditional methods of soil stabilization (Osuagwu, 2011). The advantages of vegetation include protection against wind; increased water infiltration; protection against raindrop impact, reinforcement of soil by roots, reduction of surface water runoff; interception of rainfall and protection against erosion by surface water flow.

\subsection{Solid Waste Management}

Solid waste management is the collection, transport, processing and disposal, managing and monitoring of waste materials. The term usually relates to materials produces by human activity and the process is generally undertaken to reduce their effect on health and land (Wikipedia). When every house is mandated to have a waste bin big enough to hold solid waste for some days and there are trucks that moves from street to street to collect them and dispose them far away from human residence, the unscrupulous disposal of waste materials anywhere and on water courses will be eradicated.

\subsection{Recommendation}

It is recommended that the three tiers of government should:

(i) Improve the finance of erosion control unit in the state.

(ii) Improve on environmental education.

(iii) Formulate sound policies and increase legislative measures.

(iv) Enact environmental protection laws so that an average person in the city plant trees and cover crops in his premises.

(v) Train farmers on the new methodology of farming, which will discourage soil erosion/land degradation caused by poor farming system.

\subsection{Conclusion}

The need to arrest the trend in soil erosion in Auchi is very important. The preventive measures listed above should be implemented because human activity is said to be the major cause of erosion in the study area, if the people living in particular geographical location adheres to healthy practices that are environmentally friendly, the environment will also cooperate, the loss of properties and lands will become a history.

The neglect of Erosion problems in Africa is creating attention in many quarters within and outside the continent. Erosion occurs as a result of both natural and man-made problems that span over time. Therefore, the best solutions for some are found with prevention and early cure. But because these simple techniques or strategies are not applied, the situations get worse and worse day-by-day. The mechanisms for checking, preventing, and protecting erosion belong mainly to the world of construction and to some extent manufacturing and biotechnology. When the problem involves preventing erosion, it is best solved by means of construction and plant biotechnology. When it involves checking and protecting deep or slope erosions, manufacturing would then constitute part of the solution. It is important to emphasize that the most creative solutions are the ones designed or targeted against the causes, sources, and cradles. Solutions to erosion problems are not cheap especially when belated efforts are made as in the cases currently found in Nigeria.

\section{References}

Egbai O. O., Samuel U U., Eric J. N., Ewa E. E. and Uquetan U. I. (2011) “Assessment of Soils Susceptibility to 
Erosion Menace in Calabar Metropolis, Cross River State, Nigeria” J Hum Ecol, 36(3): 205-209 (2011).

Egboka C. Integrated strategies and costing for the permanent control of floods, soil and gully erosion in Anambra State, Nigeria. (1993). P. 30. Awka Nigeria.

FGN (1997). Vision 2010: Report of the Vision 2010 Committee, Main Report, Abuja

Humberto Blanco and Rattan Lal (2008) "Principles of Soil Conservation and Management" Springer Science+Business Media B.V.

Lesschen J.P, Verburg P.H, Steal S.J (2005) "Statitistical methods for analyzing the spatial dimension of changes in land use and farming systems" LUCC Report Series No 7. The International Livestock Research Institute, Nairobi and LUCC.

Mbajiorgu C. C. (2008) "Ecological Problems Identification within Watersheds in Nigeria" Journal of Agricultural Engineering and Technology (JAET), Volume 16 (N0. 1) June, 2008

Nnebedum L. (2013); Concept of Soil Erosion, Effects and Control Measures 21 February, 2013 in Orient: Newspaper ppl.

Ojeifo Magnus O. and Akhimien Francis O. (2013) "Pattern of Fencing and Impacts in Urban Auchi, Edo State, Nigeria" International Journal of Physical and Human Geography Vol. 1, No.1, March 2013, pp.26-34

Ojo, G. J. A. (1973); The Status of Environmental Management in Nigeria". Paper Presented at the Conference on Environmental Resources Management in Nigeria. University of Ife, July 1973.

Osuagwu, J.C (2011) "The Use of Vegetation As An engineering Material" Inter-World Journal of Science and Technology VOL. 4 NO. 2:8-14

Uche Okeke (2012) "Demographic factors as causes of Soil Erosion in Anambra State" Journal of Agriculture and Veterinary Sciences Vol. 4, December 2012. Cenresin Publications www.cenresinpub.org ISSN 2277-0062 www.wikipedia.com/environmentaleducation. 